\title{
Self-cleaning perovskite type catalysts for the dry reforming of methane
}

\author{
María Natividad Pérez-Camacho a, Jehad Abu-Dahrieh a, Alexandre Goguet a, Kening Sun b, \\ David Rooney a,* \\ ${ }^{a}$ CenTACat, School of Chemistry and Chemical Engineering, Queen's University Belfast, Belfast, Northern Ireland, BT9 5AG, UK \\ ${ }^{\mathrm{b}}$ Department of Chemistry, Harbin Institute of Technology, Harbin 150001, Heilongjiang, China
}

\section{A R T I C L E I N F O}

\section{Article history:}

Received 13 June 2014

Accepted 1 July 2014

Published 20 August 2014

\section{Keywords:}

Biogas

Reforming

Perovskite

Oxygen mobility

Dopant

\begin{abstract}
A B S T R A C T
Gas-to-liquid processes are generally used to convert natural gas or other gaseous hydrocarbons into liquid fuels via an intermediate syngas stream. This includes the production of liquid fuels from biomass-derived sources such as biogas. For example, the dry reforming of methane is done by reacting $\mathrm{CH}_{4}$ and $\mathrm{CO}_{2}$, the two main components of natural biogas, into more valuable products, i.e., $\mathrm{CO}$ and $\mathrm{H}_{2}$. Nickel containing perovskite type catalysts can promote this reaction, yielding good conversions and selectivities; however, they are prone to coke laydown under certain operating conditions. We investigated the addition of high oxygen mobility dopants such as $\mathrm{CeO}_{2}$, $\mathrm{ZrO}_{2}$, or YSZ to reduce carbon laydown, particularly using reaction conditions that normally result in rapid coking. While doping with YSZ, YDC, GDC, and SDC did not result in any improvement, we show that a $\mathrm{Ni}$ perovskite catalyst $\left(\mathrm{Na}_{0.5} \mathrm{La}_{0.5} \mathrm{Ni}_{0.3} \mathrm{Al}_{0.7} \mathrm{O}_{2.5}\right)$ doped with $80.9 \mathrm{ZrO}_{2} 15.2 \mathrm{CeO}_{2}$ gave the lowest amount of carbon formation at $800^{\circ} \mathrm{C}$ and activity was maintained over the operating time.
\end{abstract}

(C) 2014, Dalian Institute of Chemical Physics, Chinese Academy of Sciences. Published by Elsevier B.V. All rights reserved.

\section{Introduction}

Green sources of energy are continually being investigated as alternatives to fossil fuels, and among these, biogas, which is derived from the anaerobic digestion of biomass, is interesting from both a financial and environmental point of view. Biogas is a secondary energy carrier that can be manufactured from a range of organic materials resulting in the production of methane that can be cleaned and transported or, as is more commonly the case, used for the generation of on-site energy $[1,2]$. The main components of biogas are methane $(55 \%-70 \%$ in volume) and carbon dioxide (30\%-45\% in volume) with ppm levels of other light gases and water [3]. This mixture of $\mathrm{CO}_{2}$ and $\mathrm{CH}_{4}$ makes biogas interesting for the dry reforming of methane (DRM) reaction $\left(\mathrm{CH}_{4}+\mathrm{CO}_{2} \leftrightarrow 2 \mathrm{CO}+2 \mathrm{H}_{2}, \Delta H^{0}=247 \mathrm{~kJ}\right.$ $\mathrm{mol}^{-1}$ ). Producing syngas using this method is considered cost effective [4,5] relative to the separation of $\mathrm{CO}_{2}$ and the steam reforming of methane. However, there are difficulties in producing commercial catalysts with both high activity and stability and a resistance to carbon accumulation [6]. Many catalysts have been studied to date, and while metals from groups 8,9 , and 10 can be used, $\mathrm{Ni}$ is often studied because of a combination of availability and price [7].

Perovskite structures containing Ni and a complex of mixed metallic oxides have been reported for steam reforming, partial oxidation, and dry reforming. It has been shown that perovskite type oxides fulfil the requirements of high metal dispersion and thermal stability [8]. The use of $\mathrm{ABO}_{3}$ perovskite oxides, where the A-site cation is a rare earth and/or alkaline earth, and the B-site cation is a transition metal, has increased recently [9]. A common DRM structure is $\mathrm{LaNiO}_{3}$ where it has been found that the addition of alkali metals or rare earth elements helps to

*Corresponding author. Tel: + 44-28-90974050; Fax: + 44-28-90974687; E-mail: d.rooney@qub.ac.uk 
reduce carbon deposition $[10,11]$ while the dilution of $\mathrm{Ni}$ in the metallic particles by a second metal such as $\mathrm{Mn}, \mathrm{Fe}, \mathrm{Cu}$, or $\mathrm{Al}$ helps to prevent sintering [12]. For example, Na0.5La0.5Nio.3$\mathrm{Al}_{0.7} \mathrm{O}_{2.5}$ is a catalyst that has shown very good performance [13].

While sintering is a common form of deactivation, carbon accumulation cannot be completely avoided and can occur rapidly under certain operating conditions. Given its importance, carbon formation in reactions involving methane has been widely investigated over the past few decades. The degree of coking is dependent on the balance between the formation and the removal of coke; and this is why the term "coke accumulation" is suggested to be more accurate than coke formation [14]. Even after many investigations, all the aspects of carbon formation/accumulation have not been fully explained because of its complexity.

One way to avoid carbon formation during the reforming of hydrocarbons is through the use of a high oxygen mobility co-catalyst such as $\mathrm{CeO}_{2}$ or $\mathrm{ZrO}_{2}$, which helps in the gasification of carbon in the same time frame as its production, i.e., the production of a self-cleaning surface. Such materials have been used successfully in solid oxide fuel cells (SOFCs), and their success in that field suggests that they can also find application in DRM [15].

The materials that are of most interest for DRM are those that are used as electrolytes in the SOFC. The requirements for an efficient electrolyte are high ionic conductivity, low electronic conductivity, stability in both oxidizing and reducing environments, good mechanical properties, and long-term stability. Three systems are widely used for SOFCs, and these are YSZ, strontium- and magnesium-doped lanthanum gallate (LSGM), and gadolinium- or samarium-doped ceria (CGO or CSO). The lowest temperature at which these systems can work depends on a combination of ionic conductivity and the minimum film thickness used in the fuel cell [16].

Oxygen ion electrolytes can be divided into several groups: fluorite-based systems (doped bismuth oxide, zirconia, ceria, pyrochlore); perovskites and related structures (lanthanum gallate, brownmillerities, BiMeVOX); La-MOX and apatites. All these have limitations, and the search for the best system is still ongoing [16].

A recent review by Wang et al. [14] in 2013 discussed SOFCs using methane as a fuel and an anode based on nickel. In this application it was found that the Ni needed to be doped to increase its stability and to reduce carbon deposition. The dopants most commonly used are scandium, YSZ, ceria, perovskites, and even carbon materials $[17,18]$. In fact, most of the materials used were very similar to those that have already been used for DRM. Herein, the reduction of coke by the introduction of another metal oxide to the surface of the original catalyst e.g. ceria, zirconia, or YSZ to reduce coking will be demonstrated.

\section{Experimental}

\subsection{Catalyst preparation}

\subsubsection{Preparation of perovskite catalytic precursors}

A sol-gel method was used to prepare the mixed oxide $\mathrm{Na} 0.5 \mathrm{La} 0.5 \mathrm{Ni}_{0.3} \mathrm{Al}_{0.7} \mathrm{O}_{2.5}$ [13]. Initially, precursor solutions were prepared by dissolving the raw materials into previously heated propionic acid. The precursor reagents $\left(\mathrm{La}\left(\mathrm{NO}_{3}\right)_{3} \cdot 6 \mathrm{H}_{2} \mathrm{O}\right.$, $\mathrm{Al}\left(\mathrm{NO}_{3}\right)_{3} \cdot 9 \mathrm{H}_{2} \mathrm{O}, \mathrm{Ni}\left(\mathrm{NO}_{3}\right)_{2} \cdot 6 \mathrm{H}_{2} \mathrm{O}$, and $\mathrm{NaNO}_{3}$ ) were separately dissolved in the minimum volume of hot propionic acid at atmospheric pressure and $90{ }^{\circ} \mathrm{C}$. All reagents had a purity of > 99\% and were supplied by Sigma-Aldrich Ltd. After dissolution, each solution was mixed and stirred at atmospheric pressure and $130^{\circ} \mathrm{C}$ for $120 \mathrm{~min}$. The propionic acid was then distilled in a reflux process until the formation of a gel was observed, which was dried at $90^{\circ} \mathrm{C}$ overnight and then calcined in a static air atmosphere at $725^{\circ} \mathrm{C}$ for $4 \mathrm{~h}$. After calcination, the catalyst was characterized.

\subsubsection{Addition of high oxygen mobility materials to the perovskites}

A modification of the original perovskite catalysts was performed by adding small amounts of high oxygen mobility compounds. These compounds are summarized in Table 1. All of these were in a stable powder state and were supplied by Beijing Institute of Technology, China.

These compounds were added to the original perovskite type catalyst in different ways to investigate their impact on coke accumulation rates. The first method employed was the impregnation of the perovskite gel obtained before the drying step with the powder of each compound. Here, the gel of the perovskite precursor obtained after stirring the sample at 120 ${ }^{\circ} \mathrm{C}$ was mixed with a powder of $\mathrm{CeO}_{2}$ or $\mathrm{ZrO}_{2}$ or YSZ. The mixture was then allowed to dry and was then calcined in a static air atmosphere at $725{ }^{\circ} \mathrm{C}$ for $4 \mathrm{~h}$. The second method blended the overnight dried perovskites gel with the powder of each compound, and the resulting mixture was calcined in a static air atmosphere at $725^{\circ} \mathrm{C}$ for $4 \mathrm{~h}$. Another method consisted of ball milling the powder of perovskite, which had previously been calcined at $725{ }^{\circ} \mathrm{C}$ and was mixed with a corresponding amount of high oxygen mobility compound in powder form. Post-ball milling, the samples were recalcined at $1200{ }^{\circ} \mathrm{C}$ for 4 h. For the ball milling of the samples, a $500 \mathrm{~cm}^{3}$ sintered aluminium oxide grinding jar was used with seven $10 \mathrm{~mm}$ diameter sintered alumina grinding balls. Milling was performed in a Retsch PM 100 Planetary Ball Mill at a rotation speed of 150 rpm for $4 \mathrm{~h}$.

\subsubsection{Ceria and zirconia mixtures}

Initially, powders of a mixture of $\mathrm{CeO}_{2}$ and $\mathrm{ZrO}_{2}$ with different portions of each oxide were mixed with the Na-perovskites

Table 1

Compounds used as high oxygen mobility promoters.

\begin{tabular}{lcc}
\hline Name & Abbreviation & Formula \\
\hline Ceria zirconia & $\mathrm{CZ1}$ & $48.5 \mathrm{CeO}_{2} 48.5 \mathrm{ZrO}_{2}$ \\
Ceria zirconia & $\mathrm{CZ2}$ & $80.9 \mathrm{ZrO}_{2} 15.2 \mathrm{CeO}_{2}$ \\
Strontium-doped cerium oxide & $\mathrm{SDC}$ & $\mathrm{Ce}_{0.8} \mathrm{Sr}_{0.2} \mathrm{O}_{2}$ \\
Gadolinium-doped cerium oxide & GDC & $\mathrm{Ce}_{0.8} \mathrm{Gd}_{0.2} \mathrm{O}_{2}$ \\
Yttria-doped cerium oxide & YDC & $\mathrm{Ce}_{0.9} \mathrm{Y}_{0.1} \mathrm{O}_{2}$ \\
Yttria-stabilized zirconia & YSZ & $\mathrm{Y}_{2} / \mathrm{ZrO}_{2}$ \\
\hline
\end{tabular}


to create a catalyst with higher resistance to carbon formation.

The powders were mixed with the Na-perovskites in two different ways: the first was mixing the powder with the gel of the perovskites before the drying step while the second method was after overnight drying, as explained in Sections 2.1.1 and 2.1.2. The samples were then calcined at $725{ }^{\circ} \mathrm{C}$. These two different methods were used to study the interaction between zirconia and ceria oxide with the perovskite and their effect on DRM.

In this case, four different samples were obtained, and these were tested at three temperatures and at atmospheric pressure for $6 \mathrm{~h}$. Temperature-programmed oxidation (TPO) experiments were performed after each catalytic test to quantify the carbon produced during the experiment. In general, very stable activity in the absence of a pressure drop was observed. The feed flow was adjusted to the amount of perovskite catalyst in each sample.

Table 2 summarises the nomenclature and the ratio of perovskite to the mixture of $\mathrm{ZrO}_{2} \mathrm{CeO}_{2}$. Four different catalysts were obtained from the two mixtures of $\mathrm{ZrO}_{2} \mathrm{CeO}_{2}$ (48.5\% $\mathrm{ZrO}_{2}$ and $80.9 \% \mathrm{ZrO}_{2}$ ). The mixing techniques applied were the mixing of the gel of the perovskite before calcination (GP) or mixing with the dried gel (DGP).

\subsubsection{Other mixtures}

The gel of the perovskite catalyst obtained before the drying step was also blended with SDC, GDC, YDC, and YSZ powders. These mixtures were then allowed to dry and calcined again in a static air atmosphere at $725^{\circ} \mathrm{C}$ for $4 \mathrm{~h}$. Other mixtures of CZ2, YSZ, and CZ2 plus starch were mixed with the powder of a previoulsy calcined $\left(725^{\circ} \mathrm{C}\right)$ perovskite and ball milled, as previously described, before a further calcination at $1200{ }^{\circ} \mathrm{C}$ for $4 \mathrm{~h}$.

\subsection{Catalyst characterisation}

X-ray diffraction (XRD) analysis was carried out using a PANalytical X'pert Pro, which operates at $40 \mathrm{kV}$ and $40 \mathrm{~mA}$ using $\mathrm{Cu} K_{\alpha}$ radiation $(\lambda=0.154 \mathrm{~nm})$. Xpert data viewer software was used in conjunction with the instrument.

Scanning electron microscopy (SEM) analyses were performed using two different instruments. The first one was a Zeiss ultra 55 field emission electron microscope equipped with in-lens secondary electron and backscattered detectors. The accelerating voltage was $20 \mathrm{kV}$, and an aperture of 30-60 $\mu \mathrm{m}$ was used. The working distance was 7-8 $\mathrm{mm}$. The second system used was a FEI Quanta 250 FEG MKII with a high resolution environmental microscope (ESEM) with XT microscope

Table 2

Initial mixtures for the Na-perovskites calcined at $725^{\circ} \mathrm{C}$.

\begin{tabular}{lccc}
\hline Method $^{\mathrm{a}}$ & Promoter & $\begin{array}{c}\text { Ratio of } \\
\text { perovskite: } \mathrm{ZrO}_{2} \mathrm{CeO}_{2}\end{array}$ & $\begin{array}{c}\text { Nomen- } \\
\text { clature }^{\mathrm{b}}\end{array}$ \\
\hline Impregnation of gel & $\mathrm{CZ1}$ & $1: 0.76$ & $\mathrm{GP} 48.5$ \\
& $\mathrm{CZ} 2$ & $1: 0.60$ & GP 80.9 \\
Impregnation of dried gel & $\mathrm{CZ1}$ & $1: 0.91$ & DGP 48.5 \\
& $\mathrm{CZ} 2$ & $1: 0.79$ & DGP 80.9 \\
\hline
\end{tabular}

a Preparation method before calcination at $725^{\circ} \mathrm{C}$.

${ }^{\mathrm{b}} \mathrm{G}=\mathrm{Gel} ; \mathrm{P}=$ perovskite; $\mathrm{DG}=$ dried gel. control software. This was linked to an EDX detector. The EDX was a $10 \mathrm{~mm}^{2}$ SDD Detector-x-act from Oxford Instruments with Aztec ${ }^{\circledR}$ EDS analysis software. The SEM and EDX systems used the same chamber.

$\mathrm{N}_{2}$ adsorption measurements were conducted using a Micromeritics ASAP 2010 system. The sample was placed under vacuum for $3 \mathrm{~h}$ to remove adsorbed species such as water, followed by flushing with He for 2 min. The dry sample was then weighed and placed under vacuum to complete the purification process. The sample was then subjected to varying $\mathrm{N}_{2}$ gas pressures at the liquid nitrogen temperature, and the adsorption of $\mathrm{N}_{2}$ at these pressures was recorded to obtain an adsorption isotherm. The specific surface area was measured using the BET equation.

A post reaction TPO was performed using a quadrupole MS Hiden $^{\text {TM }}$ HPR-20 operated by MASsoft software. The TPO was conducted from room temperature to a maximum of $800{ }^{\circ} \mathrm{C}$ using a heating ramp up of $5{ }^{\circ} \mathrm{C} \mathrm{min}-1$. The feed had a total flow of $50 \mathrm{~mL} \mathrm{~min}^{-1}$ with a ratio of $20 \% \mathrm{O}_{2} / \mathrm{Ar}: 5 \% \mathrm{Kr} / \mathrm{Ar}: \mathrm{He}=2.5: 1$ : 1.5 , which is $25 \mathrm{~mL} \mathrm{~min}^{-1}$ of $20 \% \mathrm{O}_{2} / \mathrm{Ar}$, and $10 \mathrm{~mL} \mathrm{~min}^{-1}$ of $5 \%$ $\mathrm{Kr} / \mathrm{Ar}$ (using $\mathrm{Kr}$ as an internal standard for the TPO) balanced with He $\left(15 \mathrm{~mL} \mathrm{~min}^{-1}\right)$.

\subsection{Catalyst activity}

The dry reforming tests were carried out with a mixture of $\mathrm{CH}_{4}: \mathrm{CO}_{2}: \mathrm{Ne}$ in a ratio of 9.5:9.5:1. This was considered to be a suitable approximation of natural biogas while allowing for an inert gas (Neon) to be used for calibration. A GHSV of 30000 $\mathrm{cm}^{3} \mathrm{gcat}^{-1} \mathrm{~h}^{-1}$ and a total flow of $50 \mathrm{~mL} \mathrm{~min}^{-1}$ were used. The activity tests were carried out under the following conditions: temperatures of 610,800 , and $880{ }^{\circ} \mathrm{C}$ at atmospheric pressure. All the gases were supplied by BOC and had a purity greater than $99 \%$.

The catalyst bed contained $0.1 \mathrm{~g}$ of the catalyst in the form of 250-425 $\mu \mathrm{m}$ diameter pellets. This was placed in the centre of an isothermal fixed-bed reactor made of stainless steel with a $1 / 4$ inch outside diameter, and it was secured with quartz wool on both sides to prevent catalyst movement during the reaction. The bed temperature was measured using K-type thermocouples supplied by Omega UK, and these were connected to a PicoLog data acquisition unit. A schematic diagram of the system is shown in Fig. 1. The GC used was a Perkin Elmer Clarus 500 with a Hayesep DB column, and it was equipped with FID and TCD detectors.

\section{Results and discussion}

\subsection{Catalyst characterisation}

The perovskite type catalysts were characterised by XRD, SEM, and TEM. The result of the ICP-OES for $\mathrm{Na}_{0.5} \mathrm{La}_{0.5} \mathrm{Ni}_{0.3}-$ $\mathrm{Al}_{0.7} \mathrm{O}_{2.5}$ is shown in Table 3. The metal content of the perovskite catalyst and dopant mixtures were verified using EDX.

BET characterisation of the perovskite catalyst resulted in a surface area of $4.90 \mathrm{~m}^{2} \mathrm{~g}^{-1}$, which is typical of these materials [13]. The samples prepared using the other compounds (ceria, 


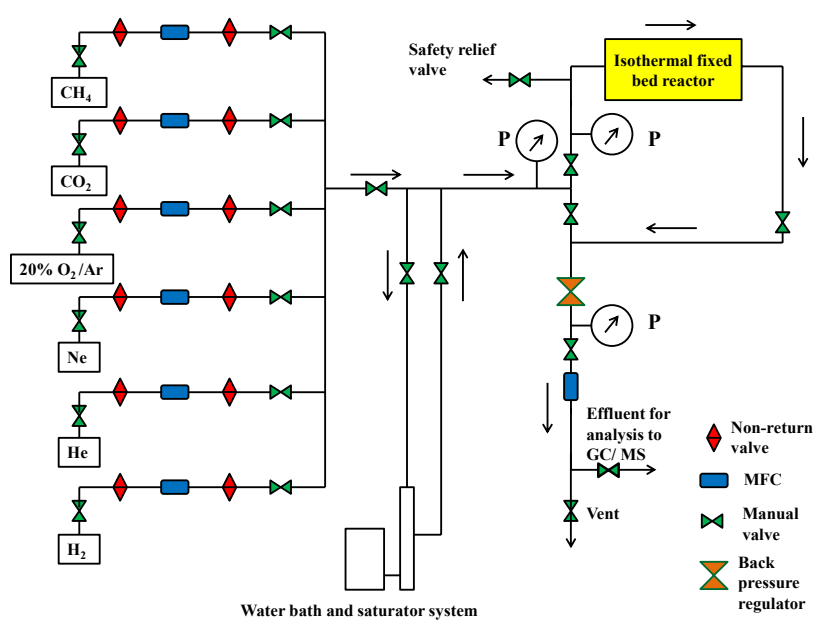

Fig. 1. Schematic drawing of the experimental set up.

Table 3

Structural properties of the fresh perovskites.

\begin{tabular}{lcccc}
\hline Sample & $\mathrm{Na} \mathrm{( \% )}$ & $\mathrm{La} \mathrm{( \% )}$ & $\mathrm{Ni}(\%)$ & $\mathrm{Al}(\%)$ \\
\hline Theoretical (from chemical equation) & 7.03 & 44.10 & 11.18 & 12.00 \\
Prepared catalyst & 3.7 & 42.8 & 11.0 & 8.5
\end{tabular}

zirconia, YSZ, etc.) were of insufficient quantity for this characterisation.

XRD analyses of all the fresh samples were performed (Fig. 2). The same structure was found for all the mixtures calcined at 725 or $1200{ }^{\circ} \mathrm{C}$.

As observed in Fig. 2(a), the addition of $\mathrm{CeO}_{2}$ and $\mathrm{ZrO}_{2}$ resulted in a decrease in the crystallinity of the structure of the perovskites, which is clearly manifested in the main peak of the samples. It is believed that an interaction between the new oxides and the previous oxides caused this change. Apart from the species previously identified in the perovskites, the $\mathrm{CeO}_{2}$ $\mathrm{ZrO}_{2}$ species was mainly found at $29^{\circ}$. The known peaks for the $\mathrm{CeO}_{2}$ and $\mathrm{ZrO}_{2}$ mixture in the pure compound are at $29^{\circ}, 34^{\circ}$, $49^{\circ}, 58^{\circ}, 61^{\circ}, 71^{\circ}$, and $79^{\circ}$ (spectra not shown), but when mixed
Table 4

Crystallite sizes calculated by the Scherrer equation for different mixtures in the fresh state.

\begin{tabular}{lcc}
\hline Preparation method & $\begin{array}{c}\text { Nomenclature of } \\
\text { mixture of perovskite }\end{array}$ & $\begin{array}{c}\text { Crystallite size } \\
\text { (nm) }\end{array}$ \\
\hline Impregnation of gel and & GP 48.5 & 21.67 \\
calcination at $725^{\circ} \mathrm{C}$ & GP 80.9 & 21.11 \\
& YSZ P & 15.18 \\
& GDC P & 14.13 \\
& SDC P & 53.05 \\
Impregnation of dried gel and & YDC P & 15.65 \\
calcination at $725^{\circ} \mathrm{C}$ & DGP 48.5 & 17.08 \\
Calcination at $1200^{\circ} \mathrm{C}$ and BM & DGP 80.9 & 23.60 \\
& CZ2 P BM & 47.19 \\
Perovskites & CZ2 P starch BM & 39.05 \\
& Calcined 725 ${ }^{\circ} \mathrm{C}$ & 30.38 \\
& Calcined $1200^{\circ} \mathrm{C}$ & 36.51 \\
\hline
\end{tabular}

with the perovskites these were attenuated. Here, the $\mathrm{CeO}_{2}$ and $\mathrm{ZrO}_{2}$ mixture was identified as the 88-2398 type using PCPDFWIN software.

The addition of YSZ and YDC etc. also influenced the crystallinity of the perovskite samples. YDC peaks were identified at $30^{\circ}$ and $50^{\circ}, \mathrm{SDC}$ at $28^{\circ}, 56^{\circ}$, and $76^{\circ}, \mathrm{GDC}$ at $28^{\circ}$, and finally YSZ at $28^{\circ}$ and $56^{\circ}$, as shown in Fig. 2(b).

The perovskites calcined at $1200^{\circ} \mathrm{C}$ gave a similar structure with less crystallinity, as shown in Fig. 2(c). The addition of $\mathrm{CeO}_{2}$ and $\mathrm{ZrO}_{2}$ had the same effect as when the calcination was performed at $725^{\circ} \mathrm{C}$.

XRD patterns of all the used samples revealed similar results to those obtained above. The particle sizes of all the samples were calculated and are summarised in Table 4. It is clear that the particle size of the perovskites increased with temperature although this did not affect the activity and carbon formation was reduced.

The impregnation of the gel seems to give smaller particle sizes (crystallite sizes) than the impregnation of the dried gel except for the SDC mixture (53 nm), which also gave the highest amount of carbon formation (shown later). In general, the mixtures containing $\mathrm{CeO}_{2}$ and $\mathrm{ZrO}_{2}$ produced materials with a

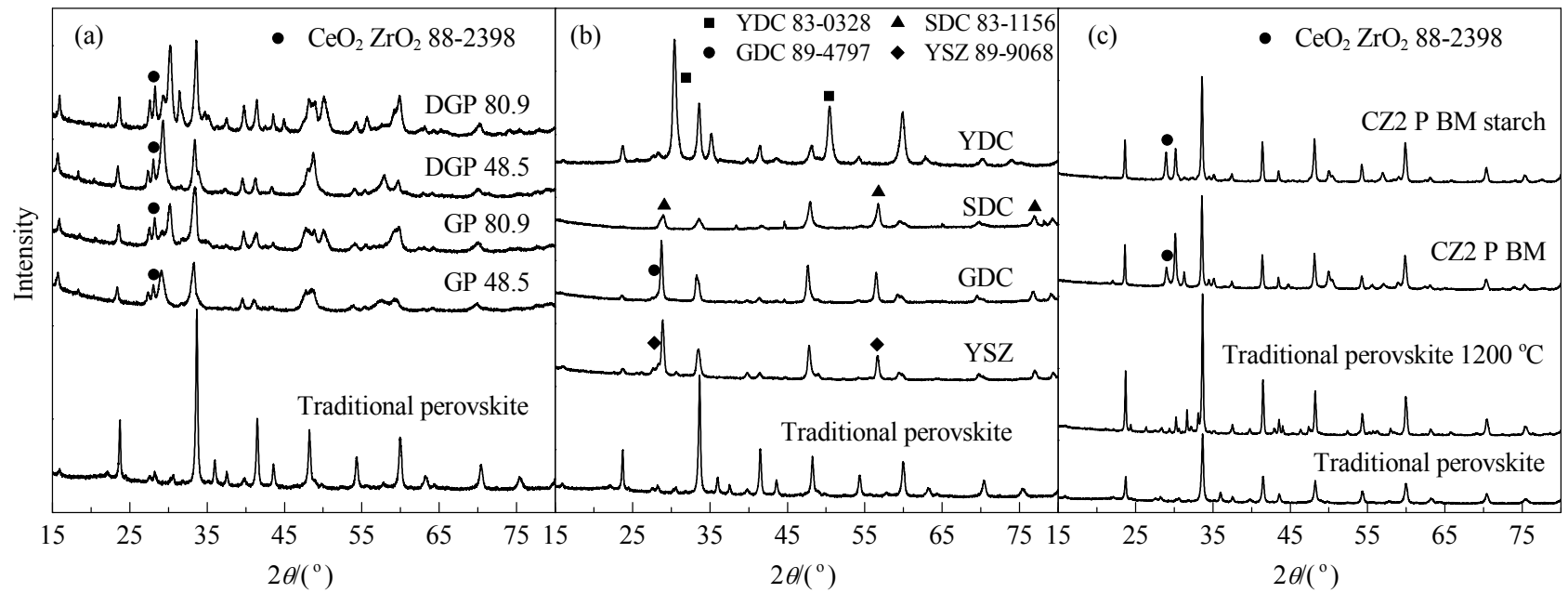

Fig. 2. XRD patterns of fresh mixtures of perovskite catalysts calcined at $725^{\circ} \mathrm{C}(\mathrm{a}, \mathrm{b})$ and $1200{ }^{\circ} \mathrm{C}(\mathrm{c})$. 


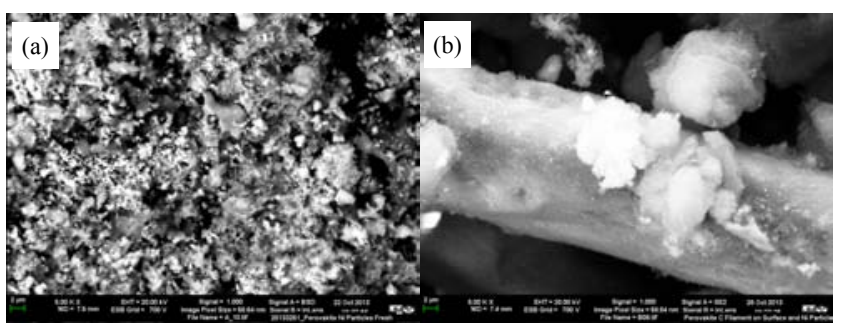

Fig. 3. SEM analysis of the $\mathrm{Na}_{0.5} \mathrm{La}_{0.5} \mathrm{Ni}_{0.3} \mathrm{Al}_{0.7} \mathrm{O}_{2.5}$ solid oxide (a) before and (b) after dry reforming at $800{ }^{\circ} \mathrm{C}, P=1 \mathrm{bar}, 100 \mathrm{mg}, F_{\mathrm{T}}=50 \mathrm{~mL}$ $\mathrm{min}^{-1}$, and $\mathrm{CH}_{4}: \mathrm{CO}_{2}: \mathrm{Ne}=$ 9.5:9.5:1.5. Image (b) includes a glass fibre.

particle size around $21 \mathrm{~nm}$ while the YSZ, GDC, and YDC mixtures had smaller particles sizes (around $15 \mathrm{~nm}$ ); however, these had lower stability. No relation was found between particle size and resistance to carbon formation.

It is important to note that the samples prepared do not correspond to a single pure perovskite. It is clear from the XRD pattern that the materials are perovskite type mixed metal oxide structures.

SEM micrographs of $\mathrm{Na}_{0.5} \mathrm{La}_{0.5} \mathrm{Ni}_{0.3} \mathrm{Al}_{0.7} \mathrm{O}_{2.5}$ were used to analyse the surface homogeneity of the powdered materials. The analysis results for the two samples, before and after the reaction, revealed the presence of carbon deposits as determined by EDX. A change in the apparent structure of the catalyst occurred, as shown in Fig. 3.

The fresh sample in Fig. 3(a) shows the formation of a po-
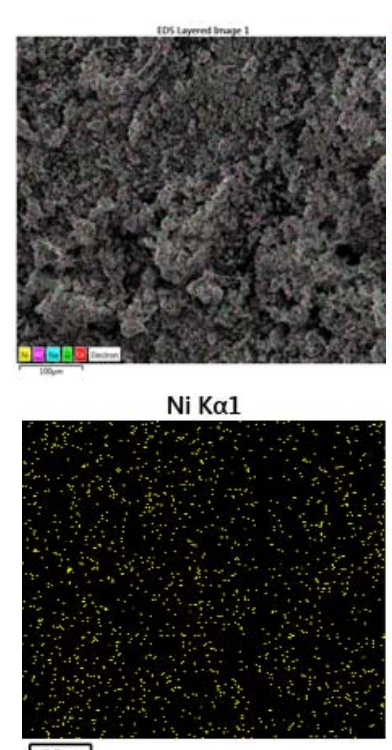

$\widetilde{100 \mu \mathrm{m}}$

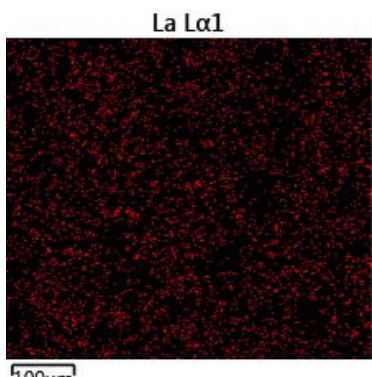

$100 \mu \mathrm{m}$

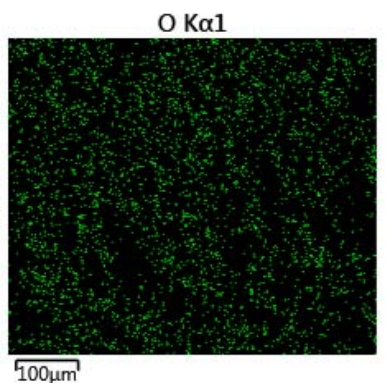

Al $\mathrm{K} \alpha 1$

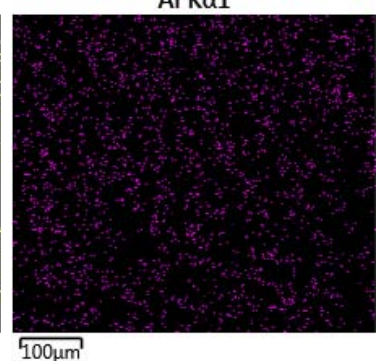

$\mathrm{Na} \mathrm{K \alpha 1 \_ 2}$

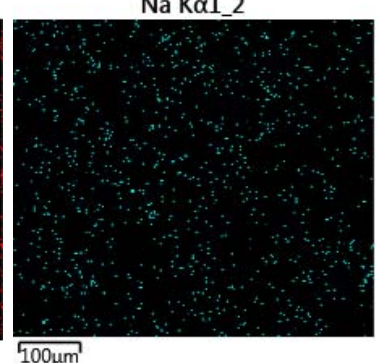

Fig. 5. EDX distribution in the fresh perovskite structure.

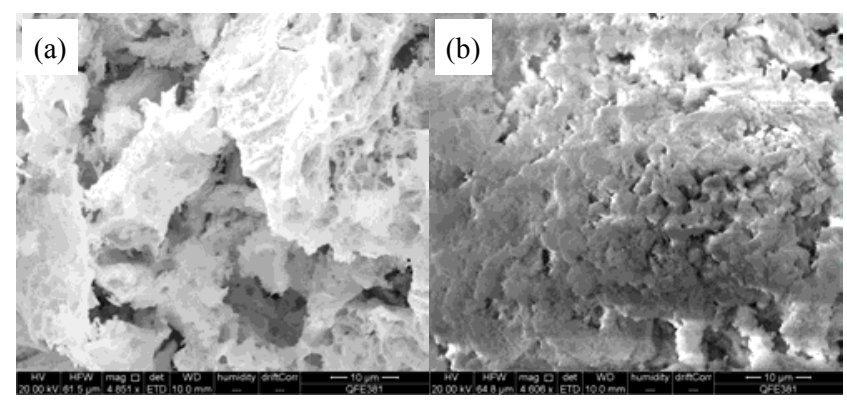

Fig. 4. SEM analysis of the $\mathrm{Na}_{0.5} \mathrm{La}_{0.5} \mathrm{Ni}_{0.3} \mathrm{Al}_{0.7} \mathrm{O}_{2.5}$ solid oxide (a) before and (b) after the dry reforming of methane. Reaction conditions: $800{ }^{\circ} \mathrm{C}$, $P=1$ bar, $100 \mathrm{mg}, F_{\mathrm{T}}=50 \mathrm{~mL} \mathrm{~min}^{-1}, \mathrm{CH}_{4}: \mathrm{CO}_{2}: \mathrm{Ne}=$ 9.5:9.5:1.

rous structure, likely during the calcination step, which comes from the decomposition of nitrates where $\mathrm{NO}_{2}$ is eliminated. This means that the nitrates present in the initial salt are responsible for the generation of a porous structure [13]. The particles in the used sample in Fig. 3(b) show signs of sintering.

Figure 4(a) shows the fresh perovskite structure and this is similar to materials in the literature [13]. As shown in Fig. 4(b) the used perovskites suggest that some sintering has occurred as previously discussed.

EDX was used to map the fresh and used perovskite sample. The fresh sample (Fig. 5) shows how Ni is well distributed over the whole surface of the analysed sample while in the used perovskite (Fig. 6) agglomerates are observed in addition to


C K $\alpha 1 \_2$

La L $\alpha 1$


Fig. 6. EDX distribution in the used perovskite structure. 
carbon formation. The same analysis was performed on samples containing $\mathrm{CeO}_{2}$ and $\mathrm{ZrO}_{2}$ where the distribution of $\mathrm{Ce}$ and $\mathrm{Zr}$ was not as good as was the case for $\mathrm{Ni}$.

TEM analysis was performed on fresh and used $\left(800{ }^{\circ} \mathrm{C}\right.$ reaction) perovskite catalysts. These two samples demonstrate that Ni particles are easily found in the used catalyst.

Figure 7 shows a TEM analysis of the fresh and used samples. The TEM of the fresh sample revealed spherical particles while the used samples seem to be agglomerated showing that even if $\mathrm{Ni}$ is present, its ratio is much lower. The absence of La and $\mathrm{Al}$ in some cases could mean that after the reaction the surface of the perovskite catalyst was modified. In this case, $\mathrm{Ni}$ seems to have migrated to the surface of the catalyst and agglomerated. In Fig. 7(b) lattice fringes were observed in the fresh perovskites and these are separated by $0.75 \mathrm{~nm}$. Here, the fresh catalyst had a range of particle sizes from 30 to $100 \mathrm{~nm}$, as determined by XRD. The used perovskite showed an increase in particle size from $36 \mathrm{~nm}$ to more than $100 \mathrm{~nm}$.

\subsection{Catalyst activity}

\subsubsection{Effect of $\mathrm{O}_{2}$ mobility additives}

The different materials used in the SOFC were used to study the impact on activity in the dry reforming reaction and to determine if these mixtures offered higher resistance to carbon formation.

\subsubsection{Addition of $\mathrm{CeO}_{2}$ and $\mathrm{ZrO}_{2}$ mixtures}

$\mathrm{ZrO}_{2}$ and $\mathrm{CeO}_{2}$ were selected for mixing with the perovskite because of their oxygen storage/release capacity, which is known to promote the carbon removal mechanisms at the metal support interfacial perimeter [19]. Some authors have reported higher $\mathrm{CH}_{4}$ and $\mathrm{CO}_{2}$ conversions because of the high $\mathrm{CO}_{2}$

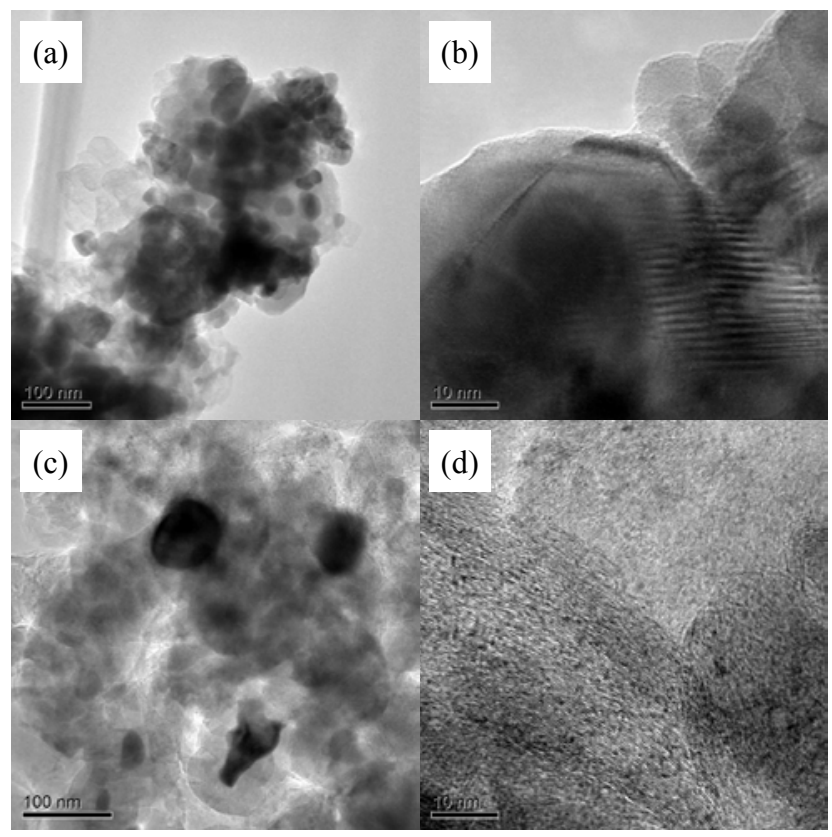

Fig. 7. TEM analysis of the $\mathrm{Na}_{0.5} \mathrm{La}_{0.5} \mathrm{Ni}_{0.3} \mathrm{Al}_{0.7} \mathrm{O}_{2.5}$ solid oxide (a,b) before and (c,d) after dry reforming at $800{ }^{\circ} \mathrm{C}, P=1 \mathrm{bar}, 100 \mathrm{mg}, F_{\mathrm{T}}=50 \mathrm{~mL}$ $\min ^{-1}$, and $\mathrm{CH}_{4}: \mathrm{CO}_{2}: \mathrm{Ne}=9.5: 9.5: 1$.
Table 5

Comparison of the catalytic activity of the mixtures for the Na-perovskites calcined at $725^{\circ} \mathrm{C}$.

\begin{tabular}{lccccc}
\hline $\begin{array}{l}\text { Catalyst } \\
\text { batch }\end{array}$ & $\begin{array}{c}T \\
\left({ }^{\circ} \mathrm{C}\right)\end{array}$ & $\begin{array}{c}X_{\mathrm{CH} 4} \\
(\%)\end{array}$ & $\begin{array}{c}X_{\mathrm{CO} 2} \\
(\%)\end{array}$ & $\begin{array}{c}\mathrm{H}_{2} / \mathrm{CO} \\
\text { ratio }\end{array}$ & $\begin{array}{c}\text { Rate } \\
\left(\mathrm{g}_{\text {carbon }} \mathrm{g}_{\text {perovsk }}{ }^{-1} \mathrm{~h}^{-1}\right)\end{array}$ \\
\hline GP 48.5 & 610 & 15.70 & 24.70 & 0.42 & 0.0076 \\
& 800 & 83.00 & 91.00 & 0.99 & 0.2552 \\
& 880 & 93.40 & 95.10 & 1.03 & 0.1860 \\
GP 80.9 & 610 & 24.00 & 36.00 & 0.55 & 0.0036 \\
& 800 & 81.00 & 91.00 & 0.95 & 0.1439 \\
& 880 & 96.30 & 97.30 & 1.03 & 0.1004 \\
DGP 48.5 & 610 & 18.00 & 31.00 & 0.60 & 0.0422 \\
& 800 & 83.00 & 89.00 & 1.00 & 0.1011 \\
& 880 & 89.00 & 89.00 & 1.08 & 0.8062 \\
DGP 80.9 & 610 & 14.00 & 28.00 & 0.52 & 0.0113 \\
& 800 & 73.00 & 83.00 & 0.96 & 0.1596 \\
& 880 & 95.00 & 95.00 & 1.06 & 0.3888 \\
Perosvkite & 610 & $22.50(45)$ & $30.30(58)$ & $0.48(0.75)$ & 0.0155 \\
& 800 & $75.00(91)$ & $80.00(95)$ & $0.96(0.96)$ & 0.4626 \\
& 880 & $95.00(95)$ & $96.00(97)$ & $0.99(0.98)$ & 0.0315 \\
\hline
\end{tabular}

adsorption capacity. This is likely responsible for the resistance of the catalyst toward carbon formation [19] although in the particular case of this study, this only occurred at $800^{\circ} \mathrm{C}$. All the results are summarised in Table 5 , and these include $\mathrm{CH}_{4}$ and $\mathrm{CO}_{2}$ conversions, the $\mathrm{H}_{2} / \mathrm{CO}$ ratio, and the rate of carbon formation. Results for the perovskite catalyst without ceria/zirconia are also presented in Table 5 for a comparison of all the catalytic tests.

Commencing with the tests at $610{ }^{\circ} \mathrm{C}$, the best catalyst for this case is GP 80.9, and this is the perovskite with the 80.9 $\mathrm{ZrO}_{2}$ and $15.2 \mathrm{CeO}_{2}$ mixture made before the gel was dried. In this case, the conversions of $\mathrm{CH}_{4}$ and $\mathrm{CO}_{2}$ were the highest at $24 \%$ and $36 \%$, respectively, with a $\mathrm{H}_{2} / \mathrm{CO}$ ratio of 0.55 , and the lowest carbon formation rate was $0.0036 \mathrm{~g}_{\text {carbon }}$ gperovsk $^{-1} \mathrm{~h}^{-1}$. None of the catalysts were close to equilibrium conversion (in brackets). In decreasing order, the rates of carbon formation were: GP 80.9 < GP 48.5 < DGP 80.9 < perovskite < DGP 48.5 . This shows that at least three of the catalysts prepared improved the resistance to carbon formation when operating at $610^{\circ} \mathrm{C}$ and at atmospheric pressure.

Table 5 shows that after the operation at $800{ }^{\circ} \mathrm{C}$ all the mixtures had higher $\mathrm{CH}_{4}$ and $\mathrm{CO}_{2}$ conversions and the $\mathrm{H}_{2} / \mathrm{CO}$ ratio was maintained at close to equilibrium, suggesting less carbon formation. After each TPO, all the samples had higher resistance to carbon formation compared to the standard perovskite catalyst. The rates of carbon formation decreased as follows: DGP 48.5 < GP 80.9 < DGP $80.9<$ GP $48.5<$ perovskites.

On the other hand, at $880{ }^{\circ} \mathrm{C}$, the standard perovskite catalyst had the highest resistance to carbon formation while all the activities were very similar and close to equilibrium. In this case the rates of carbon formation decreased as follows: perovskites < GP 80.9 < GP $48.5<$ DGP $80.9<$ DGP 48.5 .

Figure 8 shows the rate of carbon formation for these four samples and the perovskite catalyst for each reaction temperature. The $\mathrm{CO}_{2}$ profiles from the TPO experiments were obtained at similar temperatures to those of the non-doped per- 


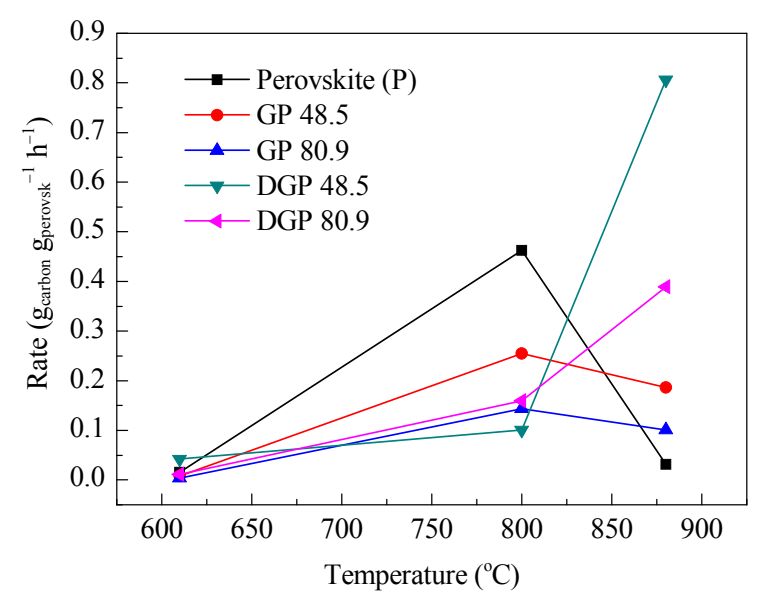

Fig. 8. Rate of carbon formation comparison for the mixtures of Na-perovskites calcined at $725^{\circ} \mathrm{C}$ vs reaction temperatures. Conditions: $P=1$ bar, $100 \mathrm{mg}$ of catalyst, $F_{\mathrm{T}}=50 \mathrm{~mL} \mathrm{~min}^{-1}$, thermal reactor.

ovskites. An example is shown in Fig. 9.

The operation at $800{ }^{\circ} \mathrm{C}$, which is the closest to industrial conditions, was undertaken under optimum test conditions, and we found that ceria and zirconia improved the carbon resistance.

The addition of $\mathrm{CeO}_{2}$ has also been reported to prevent metal sintering because of strong metal support interactions and an improvement in the thermal stability of the catalyst [20] at $800{ }^{\circ} \mathrm{C}$. The oxygen reservoir of $\mathrm{CeO}_{2}$ is believed to originate from the metal-ceria interaction because of the $\mathrm{Ce}^{4+} / \mathrm{Ce}^{3+}$ redox couple and because of metal electronic effects [20].

On the other hand, the addition of $\mathrm{ZrO}_{2}$ has resulted in an improvement of the resistance to carbon formation for Ni catalysts [21]. It is thus likely that $\mathrm{Ni}$ was not deposited directly onto the support but close to the $\mathrm{ZrO}_{2}$, which enhances $\mathrm{CO}_{2}$ dissociation and causes the gasification of the coke deposits because of the oxygen intermediates that form close to the contact between $\mathrm{Ni}$ and $\mathrm{ZrO}_{2}$.

We found that the technique of mixing the gel of perovskite before the drying step produced a more stable catalyst over a wider range of temperatures where GP 80.9 was most suitable for operation at $800^{\circ} \mathrm{C}$.

\subsubsection{Other mixtures}

Tests at $800{ }^{\circ} \mathrm{C}$ and at atmospheric pressure still resulted in carbon formation and, therefore, alternative materials were mixed with the perovskites to study their effect. The materials used as electrolytes for the SOFC were evaluated. All of these were mixed with the perovskite gel before drying, and they

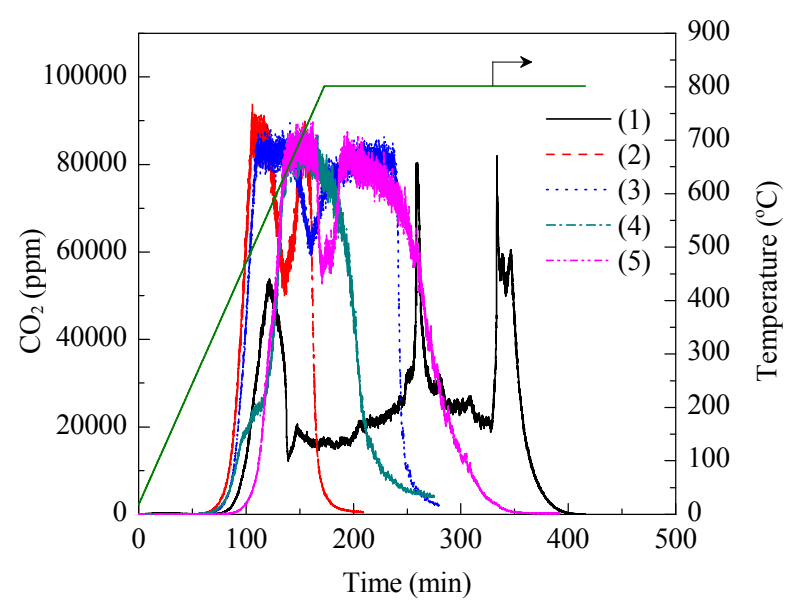

Fig. 9. $\mathrm{CO}_{2}$ profiles from the TPO of $\mathrm{Na}_{0.5} \mathrm{La}_{0.5} \mathrm{Ni}_{0.3} \mathrm{Al}_{0.7} \mathrm{O}_{2.5}$ doped with different materials and calcined at $725^{\circ} \mathrm{C}$. Test conditions: $T=800{ }^{\circ} \mathrm{C}, P$ = 1 bar, $100 \mathrm{mg}$ catalyst, $F_{\mathrm{T}}=50 \mathrm{~mL} \mathrm{~min}^{-1}, \mathrm{CH}_{4}: \mathrm{CO}_{2}: \mathrm{Ne}=9.5: 9.5: 1$. (1) perovskite only; (2) with YSZ; (3) with YDC; (4) with GDC; (5) with SDC. TPO conditions: $50 \mathrm{~mL} \mathrm{~min}^{-1}$ total flow of $20 \% \mathrm{O}_{2} / \mathrm{Ar}: 5 \% \mathrm{Kr} / \mathrm{Ar}: \mathrm{He}=$ 2.5:1:1.5, ramp of $5^{\circ} \mathrm{C} \mathrm{min}^{-1}$.

were then dried and calcined at $725{ }^{\circ} \mathrm{C}$. The materials used were YSZ, YDC, GDC, and SDC, and details and results are summarised in Table 6. The standard perovskites-type catalyst is also listed in the table for comparison.

In this case none of the samples improved the resistance of the perovskites to carbon formation. Only YSZ gave a similar resistance. Additionally, all the samples had slightly higher activity than the perovskites but this does not explain the higher coking rates.

There was a pressure drop ( 0.25 bar) only for the YDC perovskite sample and it did not give a higher amount of carbon after the TPO. This is related to the different types of carbon produced by the activity test. Figure 9 shows the TPO profiles of the experiments performed after the activity tests at $800{ }^{\circ} \mathrm{C}$. The TPOs of the four samples are shown and compared with the standard catalyst. As shown in Fig. 9, both peaks appear at the same temperature for all cases. There is no difference among the four doped perovskites and the standard catalyst. Looking at the $\mathrm{CO}_{2}$ profile the first peak evolved around $530{ }^{\circ} \mathrm{C}$ and the second at $730{ }^{\circ} \mathrm{C}$, corresponding to the graphitic carbons, $\mathrm{C}_{\beta}$ and $\mathrm{C}_{\gamma}$. It is generally accepted that hydrocarbons, which include methane, dissociate to produce monoatomic carbon $\left(\mathrm{C}_{\alpha}\right)$ that can be further gasified to produce $\mathrm{CO}$ by an oxidation reaction. Upon the excessive formation of $\mathrm{C}_{\alpha}$ it can polymerise to $C_{\beta}$, which is less reactive. This carbon, $C_{\beta}$, tends to accumulate on the surface or dissolve into the bulk of active

Table 6

Comparison of catalytic activity at $800^{\circ} \mathrm{C}$ for several mixtures of Na-perovskites calcined at $725^{\circ} \mathrm{C}$.

\begin{tabular}{lccccccc}
\hline $\begin{array}{l}\text { Compound mixed with } \\
\text { Na-perovskites }\end{array}$ & $\begin{array}{c}\text { Ratio of } \\
\text { perovskite:material }\end{array}$ & Nomenclature & $P$ drop (bar) & $X_{\mathrm{CH} 4}(\%)$ & $X_{\text {CO2 }}(\%)$ & $\mathrm{H}_{2} / \mathrm{CO}_{\text {ratio }}$ & ${\text { Rate }\left(\mathrm{g}_{\text {carbon }} \mathrm{g}_{\text {perovsk }}{ }^{-1} \mathrm{~h}^{-1}\right)}$ \\
\hline $\mathrm{YSZ}\left(\mathrm{Y} / \mathrm{ZrO}_{2}\right)$ & $0.77: 1$ & GP YSZ & 0 & 89.00 & 97.00 & 1.03 & 0.5065 \\
$\mathrm{YDC}\left(\mathrm{Ce}_{0.9} \mathrm{Y}_{0.1} \mathrm{O}_{2}\right)$ & $0.84: 1$ & GP YDC & 0.25 & 81.00 & 84.00 & 1.10 & 1.040 \\
$\mathrm{GDC}\left(\mathrm{Ce}_{0.8} \mathrm{Gd}_{0.2} \mathrm{O}_{2}\right)$ & $0.76: 1$ & GP GDC & 0 & 83.00 & 88.00 & 1.08 & 0.6858 \\
$\mathrm{SDC}\left(\mathrm{Ce}_{0.8} \mathrm{Sr}_{0.2} \mathrm{O}_{2}\right)$ & $0.70: 1$ & GP SDC & 0 & 87.00 & 94.00 & 1.03 & 1.188 \\
Perovskite & - & P & & $75.00(91)$ & $80.00(95)$ & $0.96(0.96)$ & 0.4626 \\
\hline
\end{tabular}


catalyst particles $[14,22]$.

Literature contains many examples of the application of these types of materials to reforming. According to Jacobson [16] each type offers advantages and disadvantages. For YSZ, the electrical requirements at high temperature are met, and they have good mechanical properties at high temperatures. Problems occur because of reactivity with perovskite oxide electrodes that contain lanthanum, which results in $\mathrm{La}_{2} \mathrm{Zr}_{2} \mathrm{O}_{7}$ resistive layers at high temperature. Other materials such as LSGM have higher ionic conductivity than YSZ and have shown higher compatibility with lanthanum transition metal oxides perovskite cathodes. On the other hand, the electrolytes on the anode side composed of LSGM-NiO are less compatible than the $\mathrm{Ni}$-YSZ combination because of the higher reactivity of $\mathrm{NiO}$ than Ni-YSZ with YSZ [15].

\subsubsection{Co-sintering samples $\left(1200^{\circ} \mathrm{C}\right.$ calcination)}

Because of the small improvement when using YSZ and several mixtures of ceria and zirconia, the best catalysts from the CZ2 and YSZ tests were mixed with the perovskites and calcined at $1200{ }^{\circ} \mathrm{C}$. Table 7 summarises the catalytic results at several temperatures and the carbon obtained in the post reaction TPO experiments. The sample consisting of perovskite mixed with YSZ was only evaluated at $800{ }^{\circ} \mathrm{C}$, which was the most interesting case as it is closer to industrial conditions.

At $600{ }^{\circ} \mathrm{C}$ the activity was very low while at high temperature the catalysts gave very stable performance, giving similar activity results although the YSZ mixture gave a slightly higher conversion and also higher carbon formation. Of all the samples, the best activity/carbon formation at $600{ }^{\circ} \mathrm{C}$ was obtained for the CZ2 mixture while at $800{ }^{\circ} \mathrm{C}$ the perovskite and CZ2 gave similar activity, which was slightly lower for the perovskite but this also resulted in more resistance to carbon formation. At $880{ }^{\circ} \mathrm{C}$ the $\mathrm{CZ2}$ mixture was also much better. All the activities were very close to equilibrium. A pressure drop was only found for the starch sample tested at $800{ }^{\circ} \mathrm{C}$ (1.2 bar) and with YSZ at a pressure of 1 bar.

Figure 10 shows the carbon formation rate for the samples calcined at $1200{ }^{\circ} \mathrm{C}$, and these were evaluated at several tem-

Table 7

Comparison of catalytic activity at different temperatures and at atmospheric pressure for several mixtures of Na-perovskites calcined at $1200^{\circ} \mathrm{C}$.

\begin{tabular}{lccccc}
\hline $\begin{array}{l}\text { Catalyst } \\
\text { batch }\end{array}$ & $\begin{array}{c}T \\
\left({ }^{\circ} \mathrm{C}\right)\end{array}$ & $\begin{array}{c}X_{\mathrm{CH} 4} \\
(\%)\end{array}$ & $\begin{array}{c}X_{\mathrm{CO} 2} \\
(\%)\end{array}$ & $\begin{array}{c}\mathrm{H}_{2} / \mathrm{CO} \\
\text { ratio }\end{array}$ & $\begin{array}{c}\text { Rate }\left(\mathrm{g}_{\text {carbon }}\right. \\
\left.\mathrm{g}_{\text {perovsk }} \mathrm{h}^{-1}\right)\end{array}$ \\
\hline CZ2 P BM & 610 & 11.60 & 19.20 & 0.40 & 0.0028 \\
& 800 & 81.30 & 90.60 & 0.93 & 0.0609 \\
& 880 & 91.00 & 97.00 & 1.02 & 0.0680 \\
CZ2 P starch BM & 610 & 0.00 & 0.00 & - & 0.0032 \\
& 800 & 75.00 & 76.00 & 1.10 & 0.1530 \\
& 880 & 87.00 & 98.00 & 1.04 & 0.1540 \\
YSZ P BM & 610 & - & - & - & - \\
& 800 & 85.00 & 92.00 & 1.02 & 0.4640 \\
& 880 & - & - & - & - \\
Perovskite & 610 & $27.00(45)$ & $41.00(58)$ & $0.57(0.75)$ & 0.0032 \\
& 800 & $77.00(91)$ & $87.00(95)$ & $0.87(0.96)$ & 0.0547 \\
& 880 & $91.00(95)$ & $96.00(97)$ & $0.99(0.98)$ & 0.1124 \\
\hline
\end{tabular}



Fig. 10. Rate of carbon formation for mixtures of Na-perovskites vs reaction temperature. Conditions: $P=1 \mathrm{bar}, 100 \mathrm{mg}$ catalyst, $F_{\mathrm{T}}=50 \mathrm{~mL}$ $\mathrm{min}^{-1}$, thermal reactor.

peratures under DRM conditions.

\subsubsection{Studying the origin of carbon formation}

To determine the origin of the carbon in the dry reforming system several experiments were performed with the best $\mathrm{O}_{2}$ mobility material CZ2 $\left(80.9 \mathrm{ZrO}_{2} 15.2 \mathrm{CeO}_{2}\right)$ and one that did not perform very well, YSZ.

These experiments were performed under pure $\mathrm{CH}_{4}$ or $\mathrm{CO}$ and were followed by TPO. This was done to determine if the carbon came from methane thermolysis or from $\mathrm{CO}$ disproportionation. Under CO the reaction responsible for carbon accumulation should be $\mathrm{CO}$ disproportionation (or the Boudouard reaction) while with a $\mathrm{CH}_{4}$ feed, the carbon should come from $\mathrm{CH}_{4}$ thermolysis. The results obtained are shown in Table 8 and in Fig. 11. YSZ produced more carbon from CO. For the 80.9 $\mathrm{ZrO}_{2} 15.2 \mathrm{CeO}_{2}$ sample the amount of carbon formed from $\mathrm{CO}$ was lower than that for YSZ. It was also higher than the carbon from $\mathrm{CH}_{4}$ for YSZ.

As the carbon from $\mathrm{CH}_{4}$ for $80.9 \mathrm{ZrO}_{2} 15.2 \mathrm{CeO}_{2}$ was still lower than the carbon from CO for YSZ, it can be concluded that YSZ is more prone to producing carbon than $80.9 \mathrm{ZrO}_{2} 15.2$ $\mathrm{CeO}_{2}$ and that the $\mathrm{CO}$ disproportionation reaction is mainly responsible.

Shamsi et al. [23] studied carbon formation over several different catalysts at low and high pressure. They found that when working at atmospheric pressure, for all the samples, the source of carbon was $\mathrm{CO}_{2}$ and when the pressure of the experiment was increased to 14 bar, both $\mathrm{CH}_{4}$ and $\mathrm{CO}_{2}$ contributed almost equally to carbon formation. In their study they found that a Rh-doped catalyst was most resistant to carbon deposition while a Ni catalyst was more prone to coking.

Table 8

Carbon formation for two mobility materials evaluated at $800{ }^{\circ} \mathrm{C}$ under $\mathrm{CH}_{4}$ or $\mathrm{CO}$.

\begin{tabular}{lcc}
\hline \multirow{2}{*}{ Material } & \multicolumn{2}{c}{ Amount of carbon $\left(\mathrm{g}_{\mathrm{C}} \mathrm{g}_{\mathrm{cat}}{ }^{-1} \mathrm{~h}^{-1}\right)$} \\
\cline { 2 - 3 } & Under $\mathrm{CH}_{4}$ & Under $\mathrm{CO}$ \\
\hline YSZ & 0.062 & 0.081 \\
$80.9 \mathrm{ZrO}_{2} 15.2 \mathrm{CeO}_{2}$ & 0.068 & 0.078 \\
\hline
\end{tabular}



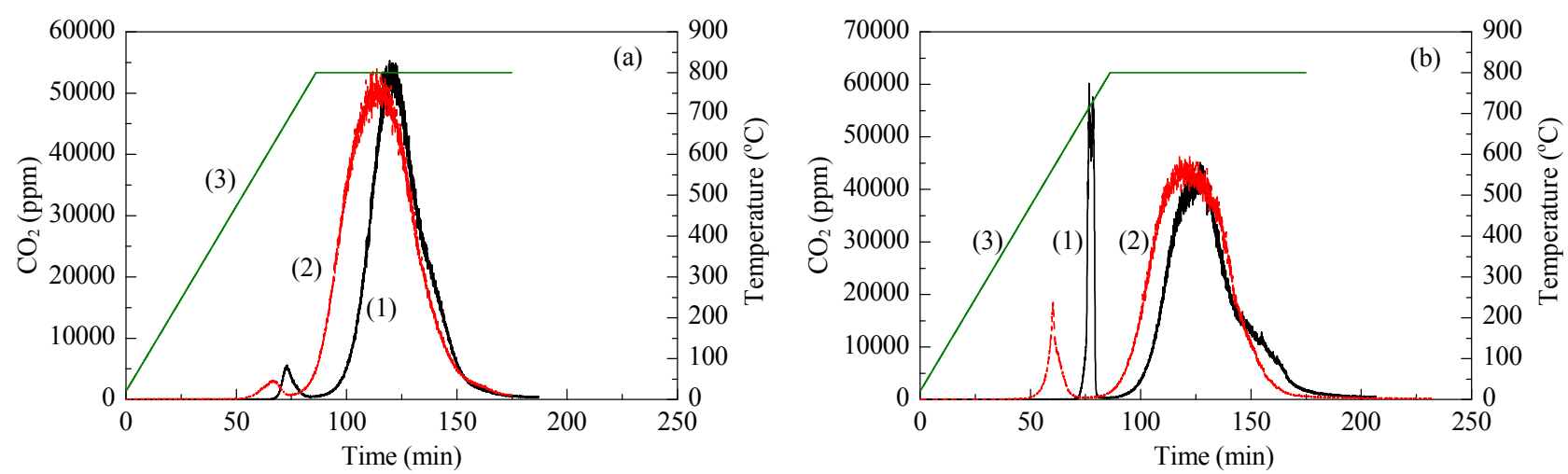

Fig. 11. $\mathrm{CO}_{2}$ profiles from the TPO of (a) YSZ and $80.9 \mathrm{ZrO}_{2} 15.2 \mathrm{CeO}_{2}$ evaluated at $800{ }^{\circ} \mathrm{C}, P=1$ bar, $\mathrm{GHSV}=30000 \mathrm{~cm}^{3} \mathrm{gcat}^{-1} \mathrm{~h}^{-1} \mathrm{vs} \mathrm{time.}(1) \mathrm{Previous}$ test under $\mathrm{CH}_{4}$; (2) Previous test under CO; (3) Temperature profile. Conditions of TPO: $50 \mathrm{~mL} \mathrm{~min}^{-1}$ total flow of 20\% $\mathrm{O}_{2} / \mathrm{Ar}: 5 \% \mathrm{Kr} / \mathrm{Ar}: \mathrm{He}=2.5: 1: 1.5$, ramp of $10^{\circ} \mathrm{C} \mathrm{min}^{-1}$.

\section{Conclusions}

The $\mathrm{Na}_{0.5} \mathrm{La}_{0.5} \mathrm{Ni}_{0.3} \mathrm{Al}_{0.7} \mathrm{O}_{2.5}$ perovskite catalyst was evaluated at $610-880{ }^{\circ} \mathrm{C}$. The variation in temperature was found to strongly influence carbon formation. The catalyst gave the highest rate of carbon formation at $800{ }^{\circ} \mathrm{C}$ and at atmospheric pressure, and this was suppressed when working at $880{ }^{\circ} \mathrm{C}$ because of the reverse Boudouard reaction. The types of carbon formed in the samples could only be completely removed in TPO experiments when operating at high temperatures, and this demonstrates the graphitic nature of the deposition.

The addition of several $\mathrm{O}_{2}$ mobility particles was performed using a range of preparation techniques. This study clearly shows that $\mathrm{CeO}_{2}$ and $\mathrm{ZrO}_{2}$ have the ability to decrease carbon formation without impacting the activity of the catalyst in the dry reforming reaction. All samples had higher resistance to carbon formation compared to the standard perovskite catalyst. The catalyst GP 80.9 (i.e., the sample prepared by mixing the perovskite gel before drying with a powder consisting of $80.9 \mathrm{ZrO}_{2} 15.2 \mathrm{CeO}_{2}$ ) gave the lowest carbon formation at 800 ${ }^{\circ} \mathrm{C}$. DGP 48.5 also resulted in lower carbon formation at $800{ }^{\circ} \mathrm{C}$, but at $880{ }^{\circ} \mathrm{C}$ it accelerated the laydown relative to the non-doped catalyst. At $880^{\circ} \mathrm{C}$, the perovskite without a modifier provided the best resistance to carbon formation followed by GP 80.9 .

Other mixtures with YSZ, YDC, GDC, and SDC were also used but with no significant improvements found. It is suggested that problems can originate from the reactivity of the perovskite, mainly the La compound, with the doping elements producing resistive layers. Further studies at higher calcination temperatures for the $80.9 \mathrm{ZrO}_{2} 15.2 \mathrm{CeO}_{2}$ mixtures did not show a clear improvement.

Overall, a carbon formation study of perovskite catalysts was undertaken using different dopants and preparation techniques. This work further demonstrates the complexity of carbon formation reactions in the DRM and the design of self-cleaning surfaces to operate under conditions that would normally result in rapid coke accumulation.

\section{Acknowledgments}

The authors would like to thank the EPSRC for funding the work.

\section{Graphical Abstract}

Chin. J. Catal., 2014, 35: 1337-1346 doi: 10.1016/S1872-2067(14)60187-X

\section{Self-cleaning perovskite type catalysts for the dry reforming of methane}

María Natividad Pérez-Camacho, Jehad Abu-Dahrieh, Alexandre Goguet, Kening Sun, David Rooney* Queen's University Belfast, UK; Harbin Institute of Technology, China



Several modified mixed perovskite type catalysts for the dry reforming of methane were prepared and tested. Modified perovskites with ceria and zirconia provided the best resistance to carbon accumulation. 


\section{References}

[1] van Foreest F. Perspectives for Biogas in Europe. NG 70. Oxford The Oxford Institute for Energy Studies, 2012

[2] Abu-Dahrieh J, Rooney D, Goguet A, Saih Y. Chem Eng J, 2012, 203: 201

[3] Abu-Dahrieh J, Orozco A, Groom E, Rooney D. Bioresour Technol, 2011, 102: 10922

[4] Asencios Y J O, Rodella C B, Assaf E M. Appl Catal B, 2013, 132-133: 1

[5] Coffey M. Filtr Sep, 2009, 46(1): 12

[6] Fidalgo B, Menéndez J A. Fuel Process Technol, 2012, 95: 55

[7] Rostrup-Nielsen J R, Sehested J, Norskov J K. Adv Catal, 2002, 47: 65

[8] Rivas M E, Fierro J L G, Goldwasser M R, Pietri E, Pérez-Zurita M J, Griboval-Constant A, Leclercq G. Appl Catal A, 2008, 344: 10

[9] Bradford M C J, Albert Vannice M. J Catal, 1998, 173: 157

[10] Slagtern A, Olsbye U, Blom R, Dahl I M, Fjellvag H. Appl Catal A, 1996, 145: 375

[11] Blom R, Dahl I M, Slagtern A, Sortland B, Spjelkavik A, Tangstad E.
Catal Today, 1994, 21: 535

[12] Cheng Z X, Wu Q L, Li J L, Zhu Q M. Catal Today, 1996, 30: 147

[13] Khalesi A, Arandiyan H R, Parvari M. Ind Eng Chem Res, 2008, 47: 5892

[14] Wang W, Su C, Wu Y Z, Ran R, Shao Z P. Chem Rev, 2013, 113: 8104

[15] Bonura G, Cannilla C, Frusteri F. Appl Catal B, 2012, 121-122: 135

[16] Jacobson A J. Chem Mater, 2010, 22: 660

[17] Fidalgo B, Menéndez J A. Chin J Catal (催化学报), 2011, 32: 207

[18] Bermúdez J M, Fidalgo B, Arenillas A, Menéndez J A. Chin J Catal (催化学报), 2012, 33: 1115

[19] Eltejaei H, Reza Bozorgzadeh H, Towfighi J, Reza Omidkhah M, Rezaei M, Zanganeh R, Zamaniyan A, Zarrin Ghalam A. Int J Hydrogen Energy, 2012, 37: 4107

[20] Djinovic P, Batista J, Pintar A. Int J Hydrogen Energy, 2012, 37: 2699

[21] Therdthianwong S, Siangchin C, Therdthianwong A. Fuel Process Technol, 2008, 89: 160

[22] Xu J K, Zhou W, Wang J H, Li Z J, Ma J X. Chin J Catal (徐军科, 周伟, 汪吉辉, 李兆静, 马建新. 催化学报), 2009, 30: 1076

[23] Shamsi A, Johnson C D. Catal Today, 2003, 84: 17 